\title{
I.ARTICLES
}

ANNA BĄK-ŚREDNICKA

Uniwersytet Jana Kochanowskiego w Kielcach

abak@ujk.edu.pl

ORCID: 0000-0001-8932-659X

\section{In search of reflective techniques in preservice teacher education: Collaboration with parents inspired by school placements}

\begin{abstract}
This paper addresses a problem which has been central in teacher education for several decades: how to encourage critical reflectivity in prospective EFL ${ }^{1}$ teachers. This problem is set within the larger context of the field of school, family and community partnerships. The rationale behind choosing this context is that there is a gap between the significance of various types of such partnerships for the well-being of the whole child, and a lack of deeper understanding of the issue among prospective teachers. The overwhelming majority of research in the matter, conducted mainly in the USA, covers the areas of pre-school, early school and special education (e.g. Lindberg 2014). Additionally, there are few research-based articles related to building the partnership skills of preservice EFL teachers. Therefore, in this paper we attempt to describe the cases of three prospective EFL teachers involved in the process of preparing small scale empirical projects related to the parents' perspectives. As shown in the paper, engagement in such long term and complex enterprises does not automatically develop the subjects' deeper understanding of the important role of various types of parent involvement in the (academic) success of children.
\end{abstract}

KEYWORDS: critical reflectivity, classroom research, collaboration with parents.

\footnotetext{
${ }^{1}$ English as a Foreign Language.
} 


\section{INTRODUCTION}

This paper focuses on selected techniques promoting critical reflectivity in prospective EFL teachers. The context is narrowed to the topic of various types of collaboration between prospective teachers and the parents of the children they teach during school placements, which is one of several areas neglected in teacher training programmes (see e.g. Epstein 2011; Błaszczyk 2014). The paper puts forward an idea of choosing topics pertaining to family and community involvement by (under)graduate students for their research projects (Epstein 2011: 9, 20). It is assumed that such long-term parent-related projects can spark prospective EFL teachers' greater interest in various types of collaboration with parents, reflect their growing understanding of the issue, and coincide with the natural progression of their critical reflection skills. This aligns with the constructivist problem-solving approach in teacher preparation (Sudzina 1997: 199).

The paper starts with a brief literature review on pre-service teachers' attitudes towards school-home relationships. Even though quality relationships are crucial for the academic success of primary pupils, too little has been done to help prospective teachers understand and distance themselves from stereotypical views of the merely supportive role of parents. Partly due to this negligence, practicing teachers tend to keep parents at a safe distance (e.g. Lortie 2002). Banasiak (2013) presents the actual state of the partnership between school, family and local community in Poland, in light of the principles of the 1999 education reform. The author explains that the culturally determined inability or unwillingness of parents and teachers to actively and closely collaborate is dictated, among other things, by their own school experience as well as the common generational experience of "socialist cooperation"2 (2013: 49). In addition, Banasiak (2013: 108) contends that the steadily growing awareness of the importance of the quality and quantity of schoolfamily contact on the part of teachers contrasts with parental lack of awareness as regards their rights in school policy decision-making. The types of school-home contacts are limited merely to parent-teacher conferences, consultations, phone calls, and traditional correspondence including notes in pupils' exercise books or emails. Banasiak (2013: 189) postulates that the situation could be improved by, for example, introducing changes in the first cycle of teacher education ${ }^{3}$.

In line with the abovementioned approach, the practical part of the paper illustrates how a diploma seminar course and practicum can be success-

\footnotetext{
2 "Socialist cooperation" is a term which refers to the Polish People's Republic, which lasted from 1947 until 1989, when life was controlled by the Soviet Union.

${ }^{3}$ See e.g. Sobierajska (2014).
} 
fully combined to prepare small-scale parent-related projects. Three seminar students who are the subjects of this case study had a personalized framework built into their school placements or workplace. The overall aim of this study was to use Epstein's model of parental involvement (2011) in order to discover to what extent, if at all, the long-term and complex process of writing a diploma project in EFL prepared future teachers to appreciate the active parental role in the education of their pupils.

\section{TEACHER-PARENT COLLABORATION: THREE MODELS}

Bronfenbrenner's (1979) ecological model of human development locates parent-teacher collaboration in a complex network of hierarchically interrelated systems. It assumes five subsystems, from proximal processes (microsystem, mesosystem $)^{4}$ to more distal environments (exosystem, macrosystem, chronosystem), which influence human growth. From the perspective of this ecological model, "the relations between home and school" are within the mesosystem which embeds microsystems (Bronfenbrenner 1993: 40). Bronfenbrenner reasons that the pupil's (further) educational success depends on the quality and quantity of child-parent interactions, as well as on "two-way communication and participation in decision making by parents and teachers" (Bronfenbrenner 1993: 40).

A corresponding version of Bronfenbrenner's ecological model of human development is Epstein's (2011) social model, with six categories of parental involvement, based on the theory of overlapping spheres of influence of family, school, and community. This evidence-based framework of "Six Types of Involvement" includes: Type 1 (Parenting), Type 2 (Communicating), Type 3 (Volunteering), Type 4 (Learning at Home), Type 5 (Decision Making), and Type 6 (Collaborating with the Community). Parenting refers to supporting parents in creating a positive home environment that is conductive to the child's learning and development. This can be achieved by means of workshops, educational films, or making home visits. Communicating consists of informing parents about the school curriculum and their children's learning outcomes by means of parent-teacher conferences, school reports, and phone calls. Volunteering refers to encouraging parents to become engaged in school life by means of participating in school trips, lessons, and

\footnotetext{
${ }^{4}$ Microsystem "refers to the relationship between a developing person and the immediate environment, such as school and family", whereas macrosystem "refers to institutional patterns of culture, such as the economy, customs and bodies of knowledge" (Bronfenbrenner 1993: 37).
} 
parent patrol programs. Learning at Home involves providing parents with strategies regarding how to work with their children at home, how to support them in doing homework, how to recognize and develop their talents, as well as how to support teachers by solving the problems which occur during lessons at home. Decision Making stands for involving parents in leadership and taking decisions concerning school policy. Collaborating with the Community involves parents in solving problems and activities to build the local community. The specific practices and challenges within each type, as stated by Epstein (2011: 387), are subject to redefinition to better match the needs and expectations of new generations of pupils, parents and teachers (Epstein 2011: 387-492). As already stated, even though there are coherent theories of the significance of parent-teacher collaboration in nurturing children's academic success, they are not applied particularly well in practice $^{5}$.

The theoretical model by Hoover-Dempsey and Sandler (1995; 1997; 2005, after Green, Walker, Hoover-Dempsey \& Sandler 2007), in turn, describes three groups of intrapersonal and interpersonal factors which contribute in the decision making process of parental home-based and school-based involvement. Overall, parental (a)motivation to engage in involvement activities comes from their motivational beliefs, their perceptions of invitations issued by teachers and school, and their perceived life context (Green et al. 2007: 533). Most importantly, the engagement is crucially dependent on "parents' interpersonal relationships with children and teachers" by means of specific child invitations and specific teacher invitations (Green et al. 2007: 540). Likewise, Rokita-Jaśkow (2013) conducted a study that investigated parental aspirations regarding very early foreign language learning. She concludes that "parental aspirations and expectations are dependent on such factors as parental level of education (especially maternal), parental age (especially paternal) and SES6" (Rokita-Jaśkow 2013: 266). As revealed in her study, the quality of home-based parental involvement in very early FLL7 correlates with these factors.

${ }^{5}$ See e.g. Epstein (2011: 7) who states that in the USA "most colleges and universities are not adequately preparing new professional educators to work with students' families and communities"; likewise, as reported by Gołębniak and Krzychała (2015: 108), in Poland we can observe the process of marginalizing the role of the pedagogical and psychological component of preservice teacher education, especially when it comes to the teaching practice. Moreover, as reported by Walczak (2012), beginning teachers in Poland do not have well developed competences to build, inter alia, quality relationships with parents.

${ }^{6}$ Socioeconomic Status.

${ }^{7}$ Foreign language learning. 


\section{PRESERVICE TEACHERS-PARENTS RELATIONS: LITERATURE REVIEW}

In this section, we review research on preservice teachers' attitude towards parental engagement. The articles were selected according to whether there were used research methods (partly) based on Epstein's (2011) model of six types of involvement. In particular, we examine research articles by McBride (1991), Katz and Bauch (1999), Graue and Brown (2003), Uludag (2008), Lindberg (2014), Brown, Harris, Jackobson and Trotti (2014), and Bąk-Średnicka (2018). This selection shows a general tendency for the overwhelming majority of teacher education studies devoted to parent-teacher rapport to be conducted in the USA.

McBride (1991) conducted an exploratory study on a sample of 271 undergraduate early childhood teacher education majors at a university in the USA in order to discover their attitudes towards five types of parental involvement with reference to Epstein's model $(1987 ; 2011)$ (Type 5 and Type 6 were merged into one category). During the process of gathering data, about one-third of the participants "were completing their student teaching placements" (McBride 1991: 7). The participants in the study filled out a questionnaire which was a modified version of a tool offered by Epstein and Dauber (1989) consisting of " 83 items measuring attitudes toward different aspects of parental involvement, as well as open-ended questions and items for demographic and background information" (McBride 1991: 7). The results show that students' attitude towards all six types of involvement is positive, but the preservice teachers believed that Type 2 (Communicating) was the most important type of parental engagement. Those participants who "were in the field working with children and their parents" showed significantly greater awareness of the importance of the engagement (McBride 1991: 11). The favourable attitude towards all varying types of family-school partnership on the part of the preservice teachers did not coincide with in-service teachers' willingness to "utilise strategies" since the number of teachers "to encourage such involvement is low (Epstein 1986, Swick \& McKnight 1989)" (McBride 1991: 6). When asked "why very few inservice teachers utilize parental involvement techniques", most of the respondents said that teachers lack knowledge and skills of how to do it (McBride 1991: 12). Also, the overwhelming majority of the respondents agreed that "teacher education programs should include a required course on parental involvement" (McBride 1991: 12-13).

Katz and Bauch (1999) undertook a study whose aim was to examine the effectiveness of The Peabody Family Involvement Initiative (PFII). Its aim was to prepare early teacher education students as well as primary and sec- 
ondary education majors for family involvement. PFII is based on the principles of Bronfenbrenner's model (1979) as well as on Epstein's six family involvement categories (Katz \& Bauch 1999: 191). In particular, the aim of the study was to answer questions related to the participants' evaluation of the initiative in order to examine if there were any differences as regards "subjects who completed the PFII and those who had no specific training" (Katz \& Bauch 1999: 192-193).

The tools used in the study were consistent with Epstein's model (2011). There were three groups of preservice and in-service teachers who participated in the study. The second group comprised 66 preservice teachers who had completed their 15-week long teaching practice as well as 67 preservice teachers who had completed "a parent / school collaboration course" (Katz \& Bauch 1999: 195). The results show that both groups of preservice teachers believed that all types of parental involvement are important, but they were of the highest opinion of "scheduled parent-teacher conferences", i.e. Type 2 (Communicating). Despite having completed the course on collaboration with parents, students still needed more training, especially in order to better understand "a teacher's role and the reality of the school setting" (Katz \& Bauch 1999: 197).

Graue and Brown (2003), in turn, investigated a sample of 130 entry-level elementary and secondary undergraduate teacher education students from a Midwestern university in the United States. The study was a part of a larger project "examining students' development of beliefs about home-school relations during a teacher education program" (Graue \& Brown 2003: 722). The data were gathered by means of a survey which represented Epstein's six categories of parental involvement (1995; 2011). The participants were asked questions on: [1] their childhood memories about their parents' involvement in school learning, [2] their conceptualisations of the roles of teachers and parents in education, and [3)] their plans to involve parents in school learning. The results show that home-school relations in preservice student teachers' memories were of Epstein's Type 2 (Communicating) and Type 3 (Volunteering) dimensions limited to "support at a distance" (Graue \& Brown 2003: 725). As regards their conceptualisations of the role of teachers and parents, "parental knowledge was not conceptualised as extending beyond the household and family" (Graue \& Brown 2003: 726). Consequently, preservice student teachers believed that a parent is a limited collaborator for a teacher, in the sense that s / he "is attentive and deferentially responds to teacher requests" (Graue \& Brown 2003: 727).

The results of the study related to preservice student teachers' plans to involve parents show that "the anticipated activities are teacher directed and relatively non-collaborative, requiring families to respond to the school's agenda" such as, for example, parent-teacher conferences or calling home 
rather than doing home visits (Graue \& Brown 2003: 729). The results of the study suggest that teacher education programmes must address the issue "of working with families" and focus on "strategies for helping prospective teachers understand the rich potentials inherent in home-school relations" (Graue \& Brown 2003: 731). According to Graue and Brown (2003), school placements should not be "focused on what is happening within the four walls of a classroom" but should also show preservice student teachers "less formal educational contexts", as well as involve them in school placements related to "case-based teaching" (Graue \& Brown 2003: 733-734).

Uludag (2008) undertook a study including a sample of 223 elementary preservice student teachers from a university in a south-eastern region of the United States. The aim of the study was to depict how the future teachers viewed the topic of parental involvement (Uludag 2008: 811). The data were gathered by means of a questionnaire which was an adapted version of The Parental Involvement Questionnaire developed by Epstein and Dauber (1989), and which consisted of "82 Likert-type scale items, 6 open ended questions, and 10 demographic questions" (Uludag 2008: 811). The results show that all preservice student teachers had a positive attitude towards all types of involvement (Uludag 2008: 12). However, they held the opinion that Epstein's Type 2 dimension (Communicating) is the most important, whereas Epstein's Type 5 dimension (parent involvement in decision-making roles) is the least important type of family-school collaboration. Notably, the subjects' opinions about their parental involvement strategies improved with time thanks to lectures, workshops, observations of parent-teacher conferences and school placements (Uludag 2008: 816).

Some interesting conclusions come also from Lindberg (2014), who conducted research on 520 preservice primary teachers as well as students of different faculties at universities in Turkey, who had participated in various courses on parental involvement. The tool used was an adapted version of the "Parent Involvement Survey" developed by Epstein and Dauber (1989). The modified version of the instrument had six dimensions: "1) Basic obligations of parents; 2) Basic obligations of schools; 3) Parent involvement in the schools; 4) Parent involvement in learning activities at home; 5) Parent involvement in decision-making roles; and 6) Parent involvement in general" (Lindberg 2014: 1354). The aim of the study was to answer questions related to the participants' views on "parent involvement subjects in the teacher training process" and "the current parent involvement practices in schools" (Lindberg 2014: 1353).

The results show that all respondents, regardless of the teacher education programs which they were involved in, had positive opinions about the varied types of parental engagement (Lindberg 2014: 1355). The most favorable 
type was "Basic Obligations of Parents", i.e. Type 2 (Communication), whereas the least favorable was Type 3 (Volunteering) (Lindberg 2014: 1357). The respondents were of the opinion that "parent involvement practices of schools and teachers were generally inadequate", mainly due to teacher-related obstacles, i.e. "unwillingness of family intervention", or family-related obstacles, i.e. their "low levels of education" (Lindberg 2014: 1357).

Brown, Harris, Jacobson and Trotti (2014) carried out quasi-experimental research at four universities in the USA whose aim was to examine the impact of Parent Teacher Education Curriculum, a Web-based Parent Teacher Education Connection (PTE Connect) curriculum, on preservice teachers' attitudes and knowledge regarding family involvement. The curriculum was also based on Epstein's model (Epstein 2001 after Brown et al. 2014: 134) in the form of six web-based modules. The participants were 1,658 candidates for teachers at primary and secondary levels in many subjects. The impact of the courses on the participants was measured by the Attitude Towards Parent Involvement Survey, designed by Epstein, Connors-Tadros, and Salinas (1993) (Brown et al. 2014: 142). The respondents chose options 1-4 on the Likert scale. The thirty survey items were divided into two parts. In part one, the respondents were asked "to rate the importance of parent involvement activities teachers use with students", whereas in part two they were asked "to rate the importance of parent involvement activities they feel parents of children in their classrooms should employ" (Brown et al. 2014: 142). The attitudes were grouped into three factors: Factor I: preservice teachers' attitudes towards partnership with parents, Factor II: preservice teachers' attitudes towards designing activities for parental involvement in children's learning, as well as Factor III: preservice teachers' attitudes towards the importance of parental engagement in activities within local community and school (Brown et al. 2014: 142). The participants completed the survey three times: at the beginning of the project, after completion of each module and then after each semester. As reported, there was a significant improvement in knowledge and attitudes between pre- and post-test scores for all six assessments (Brown et al. 2014: 144, 146). The respondents had the highest opinion of teacher responsibilities as regards contacting parents with problems (Type 2 Communicating), as well as parents responsibilities related to parental participation in committees and organizations (Type 3 Volunteering).

Bąk-Średnicka (2018) carried out a study on a group of 61 language teachers at a university in Poland, who had completed their teaching practice. Overall, the study related to preservice teachers' attitudes towards parental involvement whose aim was to find answers to the following questions: "(1) what are preservice language teachers' opinions about the most and the least important types of family-school involvement? (2) are there 
any statistically relevant associations between the preservice language teachers' opinions about the most important type of parent-teacher partnership and their direct contacts with parents during [their] practicum?" (2018: 55). The data were gathered by means of a questionnaire based on Epstein's model (2011) and pertained to the six types of involvement and two additional types i.e. Type 7 - Parents observing lessons and Type 8 - Home visits by teachers (Śliwerski 2001). The first part of the questionnaire consisted of the eight types of family-school collaboration where the participants expressed their opinions using the Likert scale, whereas the second part of the questionnaire included two questions related to teaching practice: (1) did you have any direct contact with parents during your pedagogic and didactic practice? (2) if you had direct contact with parents during your pedagogic and didactic practice, briefly describe what kind of contact you had" (Bąk-Średnicka 2018: 56). The results reveal that "there was a statistically significant difference between the group of subjects who had direct contact with parents during their teaching practice of Type 2 - Communicating and/or Type 3 - Volunteering and the group of subjects who did not have such contact" (Bąk-Średnicka 2018: 57). In particular, those preservice teachers who had direct contact with parents only of Type 2 (Communicating) were of the opinion that the most important type of family-school collaboration is of Type 4 (Learning at home) (see a pilot study by Bąk-Średnicka 2017). In turn, those participants who had direct contact with parents of Type 2 (Communicating) and of Type 3 (Volunteering) were of the highest opinion of the four types of collaboration, i.e. Type 2 (Communicating), Type 6 (Collaborating with the Community), Type 7 (Parents observing lessons), and Type 8 (Home visits by teachers). The findings correlate with those studies which show that "the more often teachers interact with parents, the more positive are their attitudes about parent involvement and listening to parent input" (Epstein 1983; Becker \& Epstein 1982, after Katz \& Bauch 1999: 189).

The findings presented so far reveal that Type 2 (Communication) dimension in Epstein's social model of parental involvement dominates prospective teachers' expectations about parent-teacher collaboration.

\section{THE BUILDING OF PRESERVICE TEACHERS' CRITICAL REFLECTIVITY RELATING TO THE PERSPECTIVE OF PARENTS: CASE-BASED TEACHING}

Case-based teaching is used in the process of educating prospective teachers (Allen, 1994; 1995, after Sudzina 1997: 204-205). A case study provides future teachers with a variety of real-life contexts which have to be 
approached by the application of "a constructivist problem-based approach to learning" (Sudzina 1997: 199). In the constructivist perspective, preservice teachers construct their knowledge and deeper understanding of "a multilayered case of a classroom dilemma" by in-depth discussions and dialogues (Sudzina 1997: 201, 204). Sudzina suggests that the role of the supervisor here is to accommodate constructive feedback to the individual differences in learning (Sudzina 1997: 203). Such a case-based teaching can lead to "clearer, more elaborate understandings of issues (Levin 1995), as well as encourage preservice teachers' cognitive growth" (Sudzina 1997: 205; Llinares \& Valls 2009: 248). Therefore, in what follows the paper describes the cases of three prospective EFL teachers involved in the process of preparing small scale empirical projects related to the perspective of parents. They submitted them in partial fulfilment of the requirements for a licentiate (bachelor's) degree. The aim of this study is to examine whether the engagement in such long-term and complex enterprises can develop prospective teachers' deeper understanding of the important role of various types of parent involvement practices. This aim corresponds with the theoretical part of the paper, where the evidence-based sources report the importance of multilevel partnerships in reducing parental stereotyping by preservice teachers (e.g. Williams \& Chavkin 1989; Greenberg 1989; Swick \& McKnight 1989, after McBride 1991: 14; Jones \& Blendinger 1994; Morris \& Taylor 1998; Epstein 1983; Becker \& Epstein 1982, after Katz \& Bauch 1999: 189; Levin 1999; Evans-Schilling 1999; Graue \& Brown 2003; Baum \& McMurray-Schwarz 2004; Uludag 2008; Ellis 2011; Foote et al. 2013; Morris, Taylor, Knight \& Wasson 1996; Tichenor 1997, after Bown et al. 2014: 137; Epstein 2005; Hoover-Dempsey et al. 2002, after Lindberg 2014: 1359; de Bruïne et al. 2014; Bąk-Średnicka 2018). The participants' opinions were analysed by using a questionnaire based on Epstein's model of parental involvement (2011).

\subsection{Research questions and instruments}

There are several questions which are raised in order to examine whether the process of carrying out long-term small-scale parent-related projects helped prospective ELT teachers gradually understand the importance of various types of parental involvement.

1. What is the preservice ELT teachers' (henceforth PSTs') overall experience (if any) as language teachers and parental status? 
2. What was the PSTs' direct inspiration for parent-related topics of their small scale empirical projects related to the perspective of parents?

3. How was the inspiration related to the context of the acquisition of data for the PSTs' small scale empirical projects related to the perspective of parents?

4. How many sites of pedagogical activities (i.e. teachers, pupils, parents, pedagogues, psychologists etc.) were involved in the PSTs' small scale empirical projects related to the perspective of parents?

5. What were the tools and participants used in the PSTs' small scale empirical projects related to the perspective of parents?

To answer questions 1-5, there were used tools such as: (1) unstructured interviews, face-to-face conversations, email messages, as well as constructive dialogues with PSTs, (2) lesson observations, (3) analyses of documents such as practicum reports and small scale empirical projects at all stages of their writing were used. The process of carrying out the projects lasted over nine months and was supervised by the author of this paper.

6. What were the PSTs' opinions about the eight types of family involvement after completing their PSTs' small scale empirical projects related to the perspective of parents?

To answer this question, a questionnaire based on Epstein's model (2011) was used. All ex-trainees were routinely asked to fill out this questionnaire (see Bąk-Średnicka 2017; 2018). It consists of two parts. In part one, PSTs expressed their opinions regarding the importance of the eight types of parent-teacher collaboration using a four-point Likert scale: unimportant, rather unimportant, important, very important. This part represented a modified version of Epstein's Six Types of Involvement and involved eight types of potential school-family contacts in total, including: Type 1 (Parenting), Type 2 (Communicating), Type 3 (Volunteering), Type 4 (Learning at Home), Type 5 (Decision Making), Type 6 (Collaborating with the Community), Type 7 (Parents observing lessons) ${ }^{8}$, and Type 8 (Home visits by teachers) ${ }^{9}$. Part two consisted of two open-ended questions that referred to PSTs' experience regarding contact with parents during the practicum (if applicable) ${ }^{10}$ : (1) Which types of parent-teacher collaboration did you observe during your pedagogic and didactic practice? and (2) Did you have any direct contacts with parents during your pedagogic and didactic practice? If yes, describe briefly what type of contacts you had.

7. How do the answers to questions 1-6 relate to one another?

\footnotetext{
8 Cf. Śliwerski (2001).

${ }^{9}$ Cf. Śliwerski (2001).

${ }^{10}$ Two PSTs were already practicing teachers and were exempt from practicum.
} 


\subsection{Participants (cases)}

The three PSTs were taking an ELT diploma seminar at The State School of Higher Education in Sandomierz (now a branch campus of the Jan Kochanowski University in Kielce) in the academic year 2015/2016. The three participants were females in their late twenties and mid-thirties. In the paper, they are addressed as PST1, PST2, and PST3.

\subsection{Results}

\subsubsection{Question 1}

PST1 was a prospective teacher in her late twenties with no previous teaching experience. She was a mother of a 9-year-old boy. PST2 was a preprimary and primary contract teacher in her late twenties with five years of experience, including three years teaching English to young learners. PST3, in turn, was a teacher of German with 15 years of experience and a prospective teacher of English. She had just started teaching English in a primary school. She was the mother of two pre-school girls.

\subsubsection{Question 2}

PST1 found inspiration for her parent-related topic, related to the educational values of language games, in teaching practice. PST2 drew her inspiration from her workplace, i.e. nursery school and the primary school where she worked as an early education English teacher. PST3's small scale project was dictated by her interests in better understanding the process of the first and second language acquisition in her children. In particular, it was inspired by a homework assignment based on recording language samples of her daughters, aged at that time 3 and 5, as each of them looked at a picture book, Frog, where are you?, by Mercer Mayer (1969) and comparing the two samples from the phonological, lexical, syntactical and pragmatic perspective.

\subsubsection{Question 3}

The project conducted by PST1 was built in the context of her teaching practice. PST2 used the context of her workplace to carry out her project, whereas PST3 used CHILDES database ${ }^{11}$ in order to gather data for her study.

\footnotetext{
${ }^{11}$ http://childes.talkbank.org/browser/index.php?url=Frogs/English-Slobin/04/04a.cha. [access: 1.06.2016].
} 


\subsubsection{Question 4}

In the case of PST1, her project involved three groups of subjects, i.e. an English teacher (and her school mentor in one), a class of 27 English language primary pupils, as well as their parents. PST2 engaged in her study 25 parents whose children attended the nursery school and the primary school where she worked as the children's English teacher. The materials for analysis conducted by PST3 were two narrations in English and German of the wordless story Frog, where are you? by two children under the age of four.

\subsubsection{Question 5}

The PSTs used the following tools:

PST1 - two questionnaires (for pupils and for their parents), based on McFarlane, Sparrowhawk and Heald (2002).

PST2 - a questionnaire for parents based on Martínez, Raquel-Amaya; Rosario Martínez; Ma Henar Pérez (2004).

PST3 - the analysis and synthesis of the materials based on Slobin (1991).

\subsubsection{Question 6}

At the end of the process of conducting their small scale projects, the PSTs filled out a questionnaire addressed to all student teachers who had completed their studies.

The case of PST1

PST1 completed the two parts of the questionnaire since she had undergone school placement. As regards the first part, she agreed that Epstein's Type 2 (Communicating), Type 3 (Volunteering), Type 4 (Learning at Home) and Type 5 (Decision Making) dimensions were very important, whereas Type 1 (Parenting) and Type 6 (Collaborating with the Community) were important. What is more, she stated that Type 7 (Parents Observing Lessons) was rather unimportant. In the second part of the questionnaire, PST1 answered two open-ended questions about her (in)direct contact with parents during her school placement where she reported that she had indirect contact with parents (observation) of Type 2 (Communicating) and Type 3 (Volunteering). In practice, she contacted parents to inform them about their children's academic achievements, as well as collaborated with parents during school events. The above findings overlap with the study by Bąk-Średnicka (2018), which revealed that those trainees who had contacted parents 
directly by means of activities within Type 2 (Communicating) and Type 3 (Volunteering) showed preferences for contact of Type 2 (Communicating), Type 6 (Collaborating with the Community), Type 7 (Parents observing lessons), and Type 8 (Home visits by teachers).

The case of PST2

PST2 opted for Epstein's Type 2, Type 3 and Type 4 dimensions as very important. She was of the opinion that Type 1, Type 5, Type 6 are important, and that Type 7 and Type 8 are rather unimportant types of collaboration.

The case of PST3

In the opinion of PST3, all Types of Involvement are either important, i.e. Type 1 , Type 5 , Type 6 , Type 7 , type 8 or very important, i.e. Type 2 , Type 3 , and Type 4.

\subsubsection{Question 7}

The overall results of the study are that the PSTs believe that familyschool partnership should be based on Epstein's 1-6 Types of contact. Only PST3, with more than a decade of teaching experience, believes that contact of Type 7 (Parents observing lessons) and Type 8 (Teachers visiting homes of their pupils) is important. PST2, in turn, distanced herself from Type 7 and Type 8. Likewise, PST1 disagrees that Type 7 is of any importance. On the other hand, PST1 thinks that four types (Type 2, Type 3, Type 4, and Type 5) are very important, whereas her more experienced counterparts chose three

Table 1. Specifications related to the participants (cases) in the study

\begin{tabular}{|l|c|l|l|l|c|c|}
\hline $\begin{array}{c}\text { Participants } \\
\text { (cases) }\end{array}$ & $\begin{array}{c}\text { Teaching } \\
\text { experience } \\
\text { (in years) }\end{array}$ & $\begin{array}{l}\text { Inspiration and } \\
\text { source of data } \\
\text { for analysis }\end{array}$ & $\begin{array}{c}\text { Subjects in- } \\
\text { volved in the } \\
\text { project }\end{array}$ & $\begin{array}{c}\text { Tools used to } \\
\text { gather data }\end{array}$ & $\begin{array}{c}\text { (Rather) unim- } \\
\text { portant types } \\
\text { of collaboration }\end{array}$ & $\begin{array}{c}\text { (Very) } \\
\text { important types } \\
\text { of collaboration }\end{array}$ \\
\hline PST1 & none & $\begin{array}{l}\text { school place- } \\
\text { ment }\end{array}$ & $\begin{array}{l}\text { ELT teacher, } \\
\text { pupils, parents }\end{array}$ & $\begin{array}{l}\text { interview, } \\
\text { 2 questionnaires }\end{array}$ & Type 7 & $\begin{array}{c}\text { Type } 1,2,3,4,5, \\
6,8\end{array}$ \\
\hline PST2 & 5 & workplace & $\begin{array}{l}\text { ELT teacher, } \\
\text { parents }\end{array}$ & questionnaire & Type 7, 8 & Type 1, 2,3, 4, 5, 6 \\
\hline PST3 & 15 & family & 2 children & $\begin{array}{l}\text { CHILDES data- } \\
\text { base }\end{array}$ & & $\begin{array}{c}\text { Type } 1,2,3,4,5, \\
6,7,8\end{array}$ \\
\hline
\end{tabular}

Eight types of parental involvement: Type 1: Parenting, Type 2: Communicating, Type 3: Volunteering, Type 4: Learning at Home, Type 5: Decision Making, Type 6: Collaborating with the Community, Type 7: Parents Observing Lessons, Type 8: Home Visits. PSTs expressed their opinions about the importance of the 8 Types of involvement using the four-point Likert scale with responses ranging from: unimportant, rather unimportant, important, very important. In this table the responses are grouped into two options, i.e. (rather) unimportant and (very) important. 
identical types as very important (Type 2 - Communication, Type 3 - Volunteering, and Type 4 - Learning at home).

We can conclude that all three PSTs strongly agree that these three abovementioned types are very important for the success of family-school collaboration. The detailed specification referring to questions 1-6 is shown in Table 1.

\section{CONCLUSION}

The study portrays three preservice teachers at different stages of their professional growth. As a practicum coordinator and a supervisor of ELT methodology seminar projects, the author has striven to provide each seminar student with a personalized framework built into their school placements or workplace. In this context, which is a minefield of problems, preservice student teachers can gain new experience and new perspectives by means of solving such real-life problems through the application of research methods (e.g. Sudzina 1997). The process of carrying out the small scale projects was a successful reflective technique of improving the PSTs' deeper understanding of the significance of a variety of contact with family. However, the professional growth of PST1 shows that "reflectivity is not an automatically developed quality" (Gabryś-Barker 2012: 73). She improved her organizational skills and succeeded in distributing, gathering and analyzing opinions from all her respondents. At the same time, she avoided involvement in discussions about the results of her study and the application of new findings into her teaching at school. She had a tendency to perceive classroom problems on the level of practical judgement and her pedagogical skills were mechanical and schematic in nature. PST1 recognized her practicum as the natural context for conducting her triangulated diploma project, but her main motivation for completing it was external in nature.

PST2 was a beginning teacher. She preferred more traditional forms of contact with parents treating them with respect. She had limited confidence in them because, as she said, they had limited confidence in her. PST2 seems to fit well in the social portrait of a schoolteacher offered by Lortie (2002). According to Lortie, 'good parents' are viewed as "distant assistants" who "use their influence with their children to further classroom efforts" (Lortie 2002: 191, 201). Therefore, such teachers believe that the parental role should be largely confined to supporting them at home, rather than entering their 'territory', especially when uninvited. PST2 reported that when she wanted to distribute her questionnaire among parents, a few of them complained to her that some questions were 'tricky' and that she was probably trying 
to prise some information from them. Moreover, when asked in the questionnaire if their children had any problems with certain subjects at school, all parents but one claimed that they were satisfied with their children's academic results. At the same time, though, PST2 told her supervisor that many of her pupils did experience such problems. This example shows that both parents and the teacher were distanced. It is, however, worth noting that the process of writing her diploma project inspired her to introduce new forms of contact with parents, such as, for example, inviting a parent to present her profession and give a practical workshop for pupils. To sum up, PST2 needed an experienced teacher, a trusted mentor to encourage her to strive to establish and maintain more advanced relationships with parents and to go beyond handling problems in a safe, predictable way.

PST3, in turn, has already become a reflective practitioner ready to treat parents as partners. The choice of the topic of her project was intrinsically motivated since she intended to elaborate on data that could help her better understand the developmental stages of her children. To sum up, PST3 was a self-motivated teacher engaged in lifelong learning.

It is to be hoped that such thoroughly analysed case studies will contribute to better understanding of various tendencies in a group of students who are preparing to become primary school ELT teachers.

\section{REFERENCES}

Banasiak, M. (2013). Wspótpraca rodziców ze szkota w kontekście reformy edukacji w Polsce. Toruń: Wydawnictwo Naukowe Uniwersytetu Mikołaja Kopernika.

Baum, A. C. / McMurray-Schwarz, P. (2004). Preservice teachers' beliefs about family involvement: Implications for teacher education. Early Childhood Educational Journal, 32 (1), 57-61.

Bąk-Średnicka, A. (2017). Preservice teachers' attitudes related to family involvement in light of their school placement experience. Theory and Practice of Second Language Acquisition, $3(2), 29-47$.

Bąk-Średnicka, A. (2018). Foreign language teacher education: School placements as a source of knowledge about parents as partners in the educational process. The International Journal of Progressive Education, 14 (6), 51-60.

Błaszczyk, K. (2014). Praktyki pedagogiczne - obszary zaniedbane i możliwości doskonalenia. In: J. Piekarski / E. Cyrańska / B. Adamczyk (eds.), Doskonalenie praktyk pedagogicznych dyskusja (pp. 123-141). Łódź: Wydawnictwo Uniwersytetu Łódzkiego.

Bronfenbrenner, U. (1979). The ecology of human development: Experiment by nature and design. Cambridge, MA: Harvard University Press.

Bronfenbrenner, U. (1993). Ecological models of human development. In: M. Gauvain, M. Cole (eds.), Readings on the development of children, $2^{\text {nd }}$ ed. (pp. 37-43). New York: Freeman.

Brown, A. L. / Harris, M. / Jackobson, A. / Trotti, J. (2014). Parent teacher education connection: Preparing preservice teachers for family engagement. The Teacher Educator, 49, 133-151. 
de Bruïne, E. J. / Willemse, M. T. / D’Haem, J. / Griswold, P. / Vloeberghs, L. / van Eynde, S. (2014). Preparing teacher candidates for family-school partnerships. European Journal of Teacher Education, 37 (4), 409-425.

Ellis, D. M. (2012). Preparing pre-service teachers to engage families in their child(ren)'s education. A case study of Oregon's teacher education programs. Portland State University Executive MPA Capstone Project. Portland: Portland State University.

Epstein, J. L. (2011). School, family, and community partnerships, $2^{\text {nd }}$ ed. Boulder: Westview Press.

Evans-Schilling, D. (1999). Preparing educational leaders to work effectively with families: The parent power project. In: M. S. Ammon (ed.), Joining hands: Preparing teachers to make meaningful home-school connections (pp. 101-121). Sacramento, CA: California Department of Education.

Foote, M. Q. / McDuffie, A. R. / Turner, E. E. / Aguirre, J. M. / Bartell, T. G. / Drake, C. (2013). Orientations of prospective teachers toward students' family and community. Teaching and Teacher Education, 35, 126-136.

Gabryś-Barker, D. (2012). Reflectivity in pre-service teacher education. A survey of theory and practice. Katowice: Wydawnictwo Uniwersytetu Śląskiego.

Gołębniak, B. D. / Krzychała, S. (2015). Akademickie kształcenie nauczycieli w Polsce - raport z badań. Rocznik Pedagogiczny, 38, 97-112.

Graue, E. / Brown, C. P. (2003). Pre-service teachers' notions of families and schooling. Teaching and Teacher Education, 19 (7), 719-735.

Green, C. L. / Walker, J. M. T. / Hoover-Dempsey, K. V. / Sandler, H. M. (2007). Parents' motivations for involvement in children's education: An empirical test of a theoretical model of parental involvement. Journal of Educational Psychology, 99 (3), 532-554.

Jones, L. T. / Blendinger, J. (1994). New beginnings: Preparing future teachers to work with diverse families. Action in Teacher Education, XVI (3), 79-86.

Katz, L. / Bauch J. P. (1999). The Peabody Involvement Initiative: Preparing preservice teachers for school collaboration. School Community Journal, 9 (1), 185-204.

Levin, P. F. (1999). Preparing teachers to connect home and school: Learning about the sociocultural contexts of teaching and learning. In: M. S. Ammon (ed.), Joining hands: Preparing teachers to make meaningful home-school connections (pp. 60-78). Sacramento, CA: California Department of Education.

Lindberg, E. N. (2014). Final year faculty of education students' views concerning parent involvement Educational Sciences: Theory \& Practice, 14 (4), 1352-1361.

Llinares, S. / Valls, J. (2009). The building of pre-service primary teachers' knowledge of mathematics teaching: Interaction and online video case studies. Instructional Science: An International Journal of the Learning Sciences, 37, 247-271.

Lortie, D. C. (2002). School teacher. A sociological study, $2^{\text {nd }}$ ed. Chicago: Chicago University Press.

McBride, B. A. (1991). Preservice teachers' attitude toward parental involvement. Teacher Education Quarterly, 18 (4), 57-67.

McFarlane, A. / Sparrowhawk, A. / Heald, Y. (2002). Report on the educational use of games. Cambridge: Shelford Studio TEEM.

Martínez, R.-A. / Martínez, R. / Pérez, M. H. (2004). Children's school assessment: Implications for family-school partnership. International Journal of Educational Research, 41, 24-39.

Morris, V. G. / Taylor, S. I. (1998). Alleviating barriers to family involvement in education: The role of teacher education. Teaching and Teacher Education, 14 (2), 219-231.

Rokita-Jaśkow, J. (2013). Foreign language learning at pre-primary level. Parental aspirations and educational practice. Kraków: Wydawnictwo Naukowe Uniwersytetu Pedagogicznego. 
Slobin, D. I. (1991). Learning to think for speaking: Native language, cognition, and rhetorical style. Pragmatics, 1 (1), 7-25.

Sobierajska, D. (2014). Metoda projektów w konstruktywistycznym modelu praktycznego kształcenia przyszłych nauczycieli. In: J. Piekarski / E. Cyrańska / B. Adamczyk (eds.), Doskonalenie praktyk pedagogicznych - dyskusja (pp. 31-46). Łódź: Wydawnictwo Uniwersytetu Łódzkiego.

Sudzina, M. R. (1997). Case study as a constructivist pedagogy for teaching educational psychology. Educational Psychology Review, 9 (2), 199-218.

Śliwerski, B. (2001). Program wychowawczy szkoty. Warszawa: Wydawnictwa Szkolne i Pedagogiczne.

Uludag, A. (2008). Elementary preservice teachers' opinions about parental involvement in elementary children's education. Teaching and Teacher Education, 24 (3), 807-817.

Walczak, D. (2012). Początkujacy nauczyciele. Raport z badania jakościowego. Warszawa: Instytut Badań Jakościowych.

Received: 28.09.2018; revised: 1.10 .2019 